\title{
Foreign Direct Investment Inflows in Ghana: Is There Any Political and Priority Influence in the Distribution among the Sectors and Regions of the Ghanaian Economy?
}

\author{
Yeboah Evans $^{1 *}$, Christiana Kesse ${ }^{2}$, Apana Gladys ${ }^{3}$, Kudakwashe Kimp Nyamoto $^{3}$ \\ ${ }^{1}$ Nanjing University of Science and Technology, Nanjing, China \\ ${ }^{2}$ Hohai University, Nanjing, China \\ ${ }^{3}$ Jiangsu University, Zhenjiang, China \\ Email: *yeboahevans56@yahoo.com, christianakesse@yahoo.com, dlagsy.luv@yahoo.com, kimp.nyamoto@yahoo.com
}

How to cite this paper: Evans, Y., Kesse, C., Gladys, A. and Nyamoto, K.K. (2018) Foreign Direct Investment Inflows in Ghana: Is There Any Political and Priority Influence in the Distribution among the Sectors and Regions of the Ghanaian Economy? Open Journal of Business and Management, 6, 973-989.

https://doi.org/10.4236/ojbm.2018.64072

Received: September 28, 2018

Accepted: October 28, 2018

Published: October 31, 2018

Copyright $\odot 2018$ by authors and Scientific Research Publishing Inc. This work is licensed under the Creative Commons Attribution International License (CC BY 4.0).

http://creativecommons.org/licenses/by/4.0/

\begin{abstract}
Political influence is taking certain vital role in foreign direct investment (FDI) inflow operations on the account of economic growth and development on Ghana's economy. To determine whether there has been any political and priority influence in the distribution of FDI registered projects over the past years, perceived strongholds of some regions in terms of presidential and parliamentary elections were considered. Using descriptive statistics approach which promotes the examination of the leverage of foreign direct investment in a quantitative mode based on the data collected from the Ghana Investment Promotion Centre between 2013 and 2017, it was realized that, these perceived strongholds of some regions received less or none of the registered projects through foreign direct investment. However, regions like the Upper East and Upper West, political strongholds of the National Democratic Congress (NDC) recorded no registered projects between 2012 and 2016 during the NDC's term of governance reflecting less or no political influence in the distribution of the registered projects accumulated through FDI. It was also revealed that, the service sector has been receiving much of the FDI projects due to its greater percentage share contribution to Ghana's gross domestic product (GDP). It is suggested that, FDI registered projects should not be centered in Greater Accra alone if the country needs a universal and equal development across the various regions.
\end{abstract}

\section{Keywords}

FDI, Political, Regions, Sectors, Economy, GDP 


\section{Introduction}

The inflow of foreign direct investment from foreign investing countries and individual investors into Ghana's economy has being playing a major role in the development and well-being of the nation's citizens and expatriates. Investment in developing countries comes with many restrictions from some foreign investing nations. These foreign investors, such as Paris Club of donors, International Monetary Fund and some global financial organizations, exercise some extent of political influence on most African governments and policy-makers for political and economic improvement. The political pressure from foreign investors turns to influence the allocation and distribution of FDI inflows into some sectors and regions within their economy at the expense of others. The longing for portfolio enhancement powers nations and multinational partnerships to look for new markets and grow their piece of the overall industry so as to contend on a universal scale [1]. The abundance of natural resources with the lack of capital and skilled labor in Ghana and some African nations encourages market and resource-seeking investment by well developed economies and developing countries, such as China and India. Resource-seeking ventures and investment happens quickly when there is the lack of capital base to build up a tremendous stock of resources or when there is a deficiency of skilled labor and expert learning [2]. For multinationals, the most important and common incentives to invest are efficiency-seeking, resource-seeking, and market-seeking [3]. The inflow of foreign direct investment from foreign investing nations comes in the form of loans and grants. On the other hand, these loans and assistance come with conditions attached to them, thereby raising concerns about how to refinance these loans in a profitable way without societal costs in the long run [1]. For instance, an investment with major conditions attached is the dam funding deal, where natural resources such as cocoa will be used to pay for the cost of credit [4]. However, upon the political influence from foreign investors on the inflows of investments into the Ghanaian economy, there are other internal factors, such as polities and priorities which influence the allocation and distributions among the various sectors and regions. Hence, this paper seeks to focus on whether there are some polities and priorities backing the distribution of foreign direct investment within the economy of Ghana.

\subsection{The Political Motives about the Regions in Ghana}

The geographical location of Ghana is in the western part of the African continent of which its neighboring countries are: Burkina Faso in the north, Cote D'Ivoire to the west, Togo in the east and to the southern boundary is the Gulf of Guinea. Democracy as a system of governance has been the basic fundamental stability of Ghana's economic and political environment over the past twenty-seven years. Instability in the political environment after Ghana gained independence from the British as their colonial master in the past was as a result of political powers and governance seized through military coups. However, the 
establishment of the 1992 constitution brought about general elections, which gave citizens the right to vote for their favorite candidate. After the country gained independence, there were numerous coups which led to a military system of government for about 20 years [5]. However, Nigeria and Ghana are the major recipients of the inflows of foreign direct investment in the West African sub-region among the other nations. Nigeria as a country with the largest population size in the West-African region and across the African continent receives much foreign direct investment inflows due to its population size, natural resources and the crude oil attracting more investors into the country's economy. Ghana on the other hand, as the second largest recipient of FDI inflows is as a result of Its abundance of natural resources such as gold, diamond and crude oil, and a stable political environment. Figure 1 below shows the values of FDI inflow in Ghana and Nigeria between 2012 and 2016 in respect to the total estimated values received in western African region within these years.

Conversely, there are ten main regions in Ghana: Ashanti, Brong-Ahafo, Central, Eastern, Greater Accra, Northern, Upper East, Upper West, Volta and Western. Greater Accra and Ashanti regions are the most populated zones in terms of Population density. However, major constituencies are being created within these regions. It is based on these constituencies that make elections very easy and flexible for eligible voters to cast their votes for both parliamentary and presidential candidates of their choice. Some regions are seen as strongholds during elections of the two most prominent political parties which are the New Patriotic Party (NPP) and the National Democratic Congress (NDC). For instance, the Ashanti and Eastern regions are the strongholds of the New Patriotic Part (NPP) of which the NPP records the highest polls, winning every election whereas Volta, Northern, Upper East and West has constantly won by the National Democratic Congress (NDC) over the last two elections period. The motive of political parties considering some regions favorite over others in line with certain economic and investment decisions affects the country's growth. During

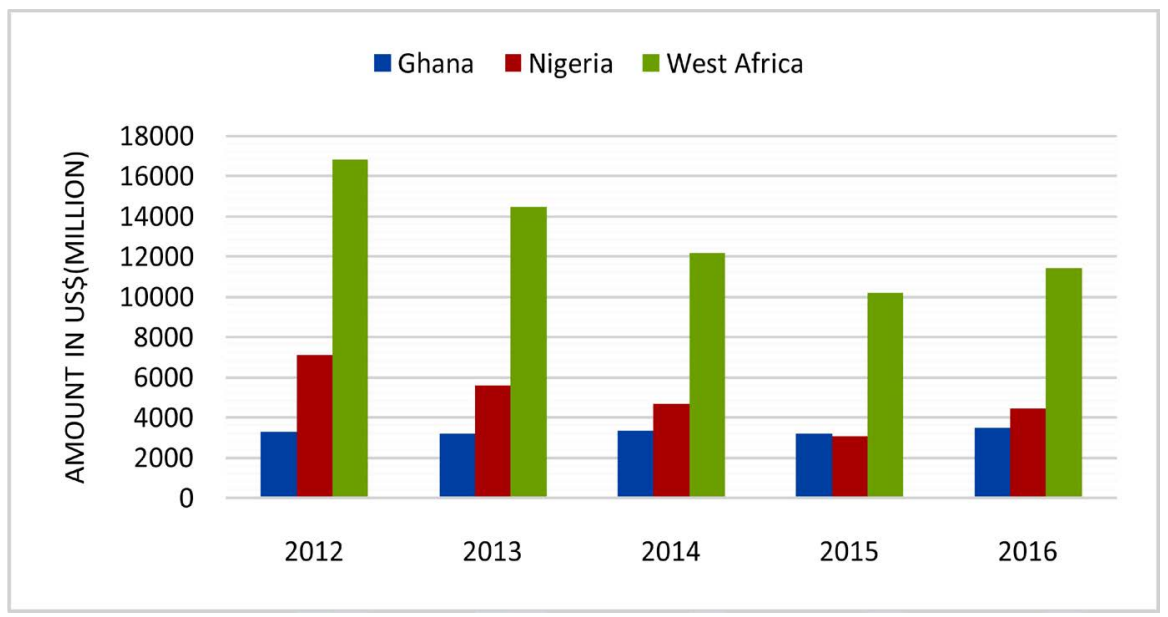

Source: UNCTAD.

Figure 1. FDI inflows values in Ghana and Nigeria between 2012 and 2016. 
every campaign era the two leading political parties target a percentage share of votes in the opponent strongholds in order to enhance their chances of winning. For instance, in the Volta Region which is the NDC's fortress, the NPP is focusing on $30 \%$ of legitimate votes in favor of the 2016 decisions, while the NDC is focusing on half of substantial votes in the Eastern Region, which is generally considered as one of the NPP's fortifications ${ }^{1}$. Infrastructural development and investment allocations are concentrated in these strongholds regions at the expense of other regions.

However, the contribution by various regions to the overall economic development comes through productions done by each administrative zones. The Brong-Ahafo region is well known for the production of cocoa and food stuffs. Major gold production in Ghana for export and domestic use are mined in the Ashanti region. Gold mining in the Ashanti region percentage share of the total gold production in Ghana outweighs the other regions. Industrialization and manufacturing are the ultimate backbone of well developed economies and some of the fasters growing countries of which most manufacturing companies and industries are located in the Greater Accra region. On the other hand, the rest of the regions equally contributes significantly to the country's well-being. Figure 2 below shows the map of Ghana.

\subsection{The Sectors Contribution to the Economy?}

Ghana's economy has been divided into eight (8) main groups according to the Ghana Investment Promotion Centre in the aspects of allocating foreign direct investment inflows from the sources of both direct and indirect injecting of money by the various foreign investing nations into these sectors. The following are sectors classified under the Ghana Investment Promotion Centre (GIPC), agriculture sector, building and construction sector, export trade sector, general trading sector, liaison sector, manufacturing sector, service and tourism sectors [6]. According to the statistics on investment reports by the Ghana Investment Promotion Centre between 1994 and 2013, the total registered projects and the total estimated cost involves in these projects were found in the manufacturing and service sectors. Sector based performance is determined by its contribution to Gross Domestic Product (GDP) and economic growth. However, over the past years the service sector contributes a greater percentage share to the gross domestic product growth and economic development. As of 2016, the service sector remains the largest contributor to the country's GDP growth. Its share of GDP increased from 54.6 percent in 2015 to 56.5 percent in 2016 and however, the sector's growth rate decreased from 6.3 percent in 2015 to 5.7 percent in 2016 [7]. The manufacturing sector equally contributes significantly to development. The Industry sector, the least growing sector with a GDP share of 24.3 percent, had its growth rate declining from -0.3 percent in 2015 to -1.4 percent in 2016 and of all the industrial operations the Electricity sub-sector the most ${ }^{1}$ http://citifmonline.com/2016/11/08/regions-breakdown-how-ndc-npp-performed-in-2012-infogra phicl 


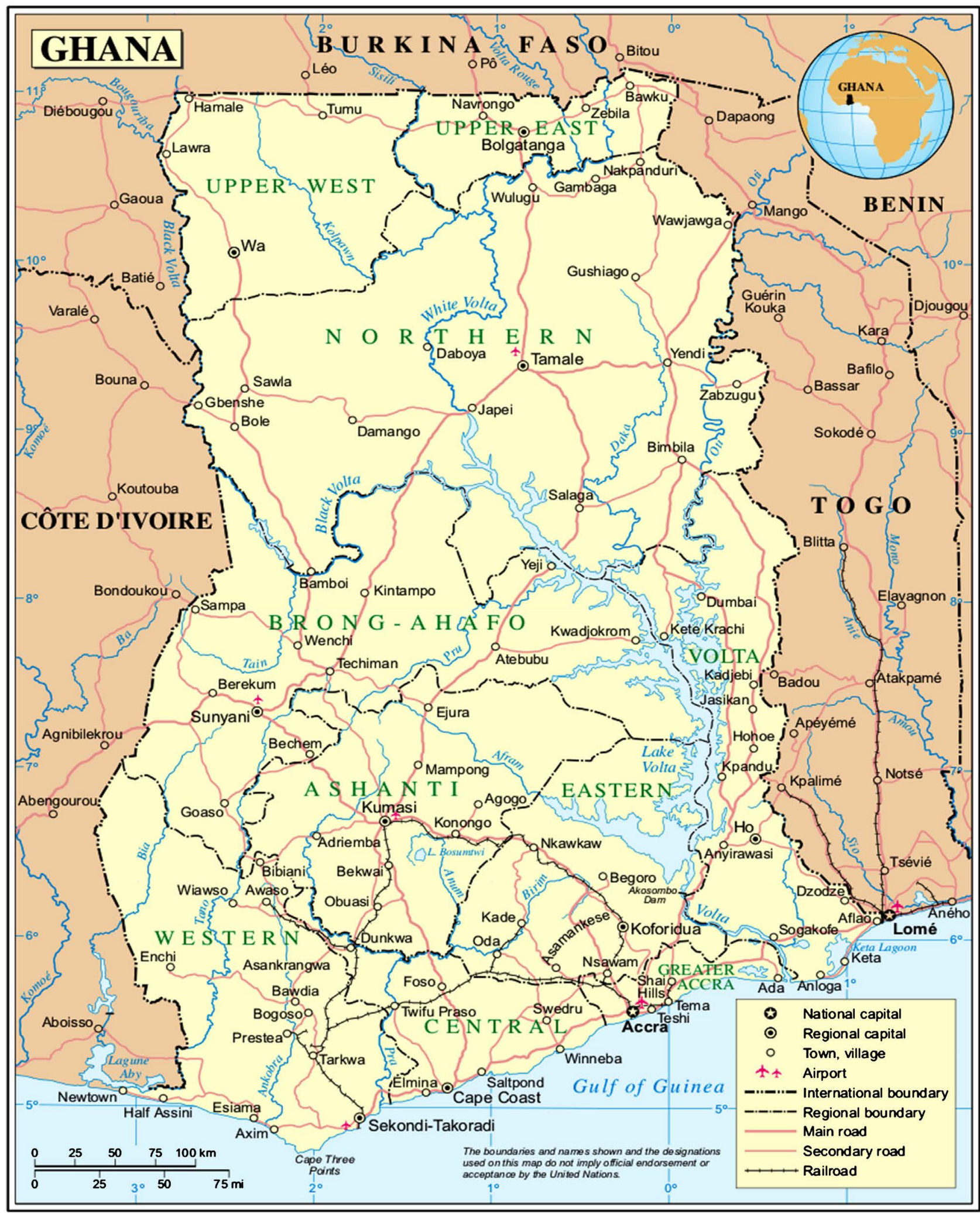

Map No. 4186 Rev. 3 UNITED NATIONS Department of Peacekeeping Operations
Cartographic Section

Figure 2. Map of Ghana (Source: http://worldofmaps.net/en/africa/map-ghana/political-map-ghana.htm). 
astounding development of 11.7 percent in 2016 [7]. The Agriculture sector extended marginally from a development rate of 2.8 percent in 2015 to 3.0 percent in 2016 and a lot of GDP, be that as it may, declined from 20.3 percent in 2015 to 19.1 percent in 2016 though the Non-Oil yearly GDP development rate expanded from 4.0 percent in 2015 to 4.9 percent in 2016 [7]. Additionally, per statistics and performance by the various sectors towards economic development indirectly determines its attractiveness to foreign investors and encourages the government to seek for further expansion and growth in their sectors. Moreover, there was much focus on both service and manufacturing sectors as per the number of recorded registered projects through foreign investment are being allocated to these two sectors. As a result of their tremendous performance toward development in the country, it turns to energize the government to look for more investors to come and invest in these sectors.

\section{Literature Review}

There are many researchers who have studied foreign direct investment in Ghana with numerous approaches and drawn different conclusions. However, there have been only few studies focusing on whether there are any political influence and priorities in the distributions of registered projects to the various sectors and regions within the economy of Ghana. This theoretical reviews on the research done on foreign direct investment will cut across the various area of studies since there are limited research work been pursued. Examining foreign direct investment in Ghana; the distribution among sectors and regions considering foreign direct investment growth, export and import of merchandise trade, the results was that, Ghana's global trading contribution to its well-being and the world's development seems to be insignificant, whereas the inflow of foreign direct investment in Ghana has grown massively, as a result of greater efforts done by the government to attract potential investors into its economy and the outcome also proved that, the Greater Accra region receiving most of the registered projects compared to the other regions whiles in the aspect of sectorial allocation the rate at which foreign direct investment was allocated to the service sector has changed as much attention being focused on manufacturing sector [5]. A literature review on the impact of foreign direct investment on economic growth and development of the Ghanaian economy; by considering foreign direct investment commitments on jobs creation and the allotment of registered projects to the different sectors based on the data gathered from the Ghana Investment Promotion Centerit was found that, there was a decrease in the quantity of projects registered by investors in 2015 and an expansion in 2017; there were two fundamental result and they are: the tourism sector performance towards the fascination of foreign direct investment and employment generating has been lessening by implication between 2013 and 2017 of which the tourism sector did not create any employment in 2017 and tourism division did not make any work in 2017 and there is likewise much spotlight on manufacturing, ser- 
vice, building \& construction and general trading sectors as lion's share of FDI inflows has been coordinated into these areas [8]. On the sectorial paradigm, almost no consideration has been given to the agricultural sector which holds the way to food security in the world and poverty reduction in developing economies such as Ghana where the sector utilizes lion's share of the dynamic working populace and in their part of study took a gander at the effect of FDI on the performance of the agricultural sector in Ghana with data over the period 1980-2013 using Johansen co-integration test [9]. Thus, FDI adds to economic growth when there is an enhancement of the infrastructure and operational abilities of the neighborhood building and construction organizations, this will prompt the expansion of income for citizens who are utilized in this sector and along these lines prompting the in general economic development of the nation whiles they additionally uncovered that most Chinese investment are centered around the manufacturing sector and this is on the grounds that, Chinese investments in Ghana were for the most part in the manufacturing sector and thus enormous investments were redirected to help the sector's activities [10]. Following the re-establishment of democratic government in 1992 and the peaceful change over of government through the ballot box in 2000, there are indications that the political circumstance has balanced out and other basic conditions which should be met to pull in FDI are macroeconomic stability, a good tax collection and investment administration, industrial peace, enhanced and transparent governance, enhanced framework (ports, roads, rail, tele-communications), and an informed and solid workforce [11]. However, from 2006 to 2010, around at least $80 \%$ or more of investments from China have been for the most part gathered in the Manufacturing, Building and Construction and General Trade sectors of Ghana. Investors must go into under-served sectors which have been unintentionally ignored and the legislature of Ghana should allot a portion of its contracts in manufacturing and building and construction sectors to domestic investors [12]. In order to obtain more specific and comparative insights into the determinants of FDI, the aggregate FDI sample was disaggregated into sectorspecific outcomes for investigation and they found this approach necessary since sectorial activities differ in composition and the lifespan of projects whereas an example is, investment in plant, equipment and machinery in manufacturing requires time to install, become operational and eventually yield profits [13]. Polities have contributed to the advancement of foreign direct investment inflows into the country's economy as each political party who gets the mandate to rule the nation dedicates much effort to create a business-friendly environment such as tax-holidays, import exemptions on agricultural and machinery imported for investment motive which turns to attract more investors. Also there have been some advantages regarding the allocation of FDI projects to some key regions and sectors. For instance, the service sector was receiving the highest percentage share of total estimated projects due to its massive contribution to the country's enhancement. However, there are some disadvantages regarding 
certain decisions taken by politicians, governments and policy-makers in respect to foreign direct investment inflows projects distribution to some regions and sectors at the expense of others. In view of this, most regions and sectors performance to the country's development have been very low to the extent that, people in regions like Northern, Upper East and Upper West continuous to suffer from high poverty and unemployment rate. Meanwhile, these regions could have benefited from FDI projects which come in the form of the establishment of new companies and enterprises to employ the people thereby reducing unemployment and poverty ratio in these regions. Foreign direct investment generates a lot of employments in the various sectors and regions, and if these projects acquire through FDI are uniformly distributed there would be a decline in the unemployment rate in some of the poorest regions whereas reducing underperformance of some sectors as well.

\section{Recent Economic Developments}

Ghana's economic effectuation advanced meritoriously in 2017 fiscal year after the crisis in 2016. According to the world bank the country's fiscal deficit declined to $6 \%$ of the gross domestic product (GDP) in 2017 from 9.3 percent in 2016, supported by a gigantic fiscal consolidation exertion. The debt to GDP proportion is assessed at $69.2 \%$ in December 2017 down from $73.4 \%$ out of 2016 mirroring a log jam in the rate of external debt accumulation, and in addition higher GDP development ${ }^{2}$. However, according to the Ghana Statistical Service recent figures published in April 2018, Ghana's economy is forecasted to have enhanced by $8.5 \%$ in 2017 from 3.6 percent a year past influenced by the mining and oil sectors. The estimated gross domestic product of Ghana as valued at about 47.33 billion US dollars in 2017. GDP in Ghana arrived at the midpoint of 10.85 USD Billion from 1960 until 2017, achieving an untouched high of 47.81 USD Billion of every 2013 and a record low of 1.22 USD Billion out of $1960^{3}$. Ghana gross domestic annual growth rate was growing at a percentage rate between 3.7 to 3.9 in 2015. Additionally, in second quarter of 2016 the gross domestic growth rate declined to 1.1 percent reflecting a poor performance of the Ghanaian economy. Due to prudent management and a sound economy with good macroeconomic indicators between 2001 to 2007, the Ghanaian economy was a major beneficiary of about USD 770 million in foreign capital inflows, which accounted for about $25 \%$ of government revenue in 2007 and 6\% of GDP in 2008 [1]. Considering sectorial contribution in 2017 to the current development in Ghana, the manufacturing is growing rapidly. The Industry part recorded the most noteworthy development rate of 16.7 percent, trailed by Agriculture (8.4\%) and the Services (4.3\%) sectors [14]. Although the service sector remains the biggest supporter to the country's gross domestic product(GDP) but its percentage share to GDP decreased from $56.2 \%$ in 2016 to $56.2 \%$ in 2017 .

${ }^{2}$ http://www.worldbank.org/en/country/Ghana/overview

${ }^{3}$ https://tradingeconomics.com/ghana/gdp 
However, the sector's development rate diminished from 5.7 percent in 2016 to 4.3 percent in 2017, the Industry sector, the highest growing sector with a GDP share of 25.5 percent, had its growth rate increasing from $-0.5 \%$ in 2016 to 16.7\% in 2017 and the Agriculture sector extended from a development rate of $3.0 \%$ in 2016 to $8.4 \%$ in 2017 [14]. Conversely, according to trading economics gross domestic product from services in Ghana arrived at the midpoint of 13,851.88 GHS million from 2006 until 2017, achieving an unequaled high of 19,554 GHS million out of 2017 and a record low of 8690.40 GHS million of every 2006, GDP from manufacturing in Ghana found the middle value of 2173.25 GHS million from 2006 until 2017, achieving a record-breaking high of 2543 GHS million out of 2017 and a record low of 1801.31 GHS million of every 2007 and GDP from construction in Ghana arrived at the midpoint of 2311.61 GHS million from 2006 until 2017, achieving a record-breaking high of 3175 GHS million out of 2017 and a record low of 1016.30 GHS million of every 2006. Figure 3 below shows Ghana’s GDP from 2013 to 2017.

\section{Data and Methodology}

This study is being focused on the analysis of foreign direct investment inflow into Ghana's economy. The paper makes use of the descriptive statistics approach which promotes the examination of the leverage of foreign direct investment in a quantitative mode. Since the various regions in Ghana are believed to be influence by the numerous political parties during election eras and also the motive of priorities in allocating and seeking for investors to invest in the various sectors and regions over the past year has been the objective of this paper to determine whether there is some extent of political and priority in seeking for investors and also in the allocation of the number projects obtain through foreign direct investment inflows. However, we considered the number of registered projects by foreign investors over the years to the various regions and sectors within the Ghanaian economy. The study makes use of data generated from

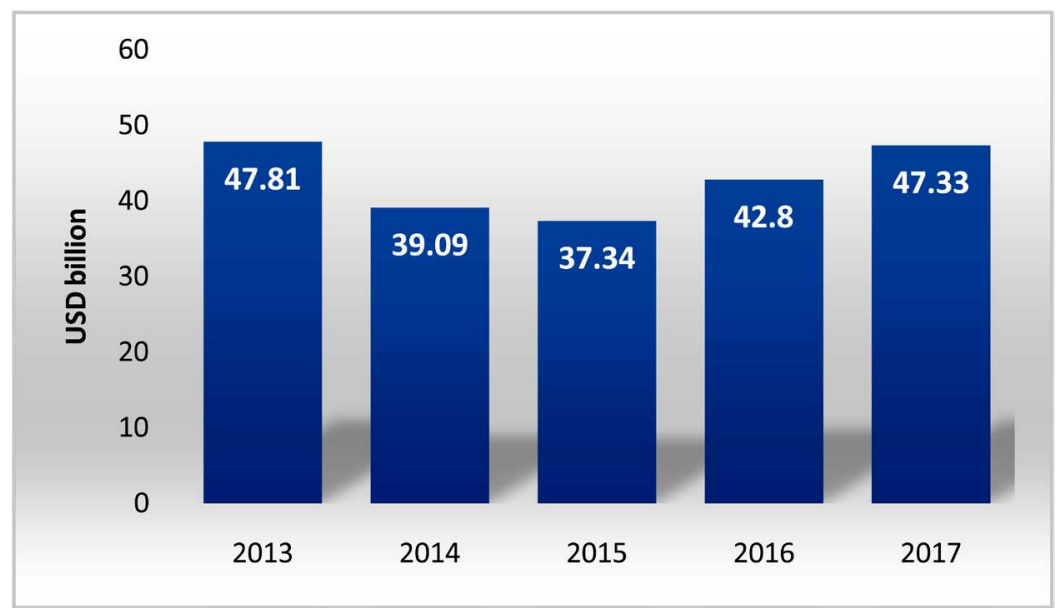

Source: Trading economics/World Bank.

Figure 3. Ghana's GDP value from 2013-2017. 
the Ghana Investment Promotion Centre the sole institution established by the government responsible for regulating, promoting and fostering investment inflows and the well-being of investors. A secondary source of data which is use to increase the sampling size of research studies particularly in the case of quantitative data collection were also considered as some relevant data were collected from trading economics, United Nations Conference on trade and Development(UNCTAD) and the World Bank.

\section{Registered Projects through Foreign Direct Investment}

The inflow of foreign direct investment into Ghana increased at an annual concoct growth rate of $41 \%$ from $\$ 636$ million to $\$ 2.527 .4$ million from 2006-2010. Between 2010 and 2013 there was an immense increased in FDI inflows from $\$ 2.527 .4$ billion to $\$ 6.821$ billion representing $46 \%$ growth rate. Registered Investments in Ghana are made up of both domestic and foreign direct investment. Over the past decades FDI inflow plays a major role in the economic development. From 2009 to 2012 FDI component of the estimated value of registered projects was of a higher value as compared to domestic investment. The total number of registered projects between 2009 and 2012 was 1,555 of which 257 was in 2009, 385 projects in 2010, 514 registered projects were in 2011 and 399 in 2012. According to the Ghana Investment Promotion Centre in 2010, the FDI component of the estimated value of registered projects was US $\$ 1.11$ billion which represent $86.59 \%$ of the total estimated value and a significant increase of US\$ $101.34 \%$ as compared to the US\$ 551.30 million recorded in 2009 and a declined in the number of registered projects by $22.37 \%$ as compared to 2011 . However, in 2013 investment fiscal year, there was 418 registered projects by foreign investors through foreign direct investment of which in the aspect of regional and sectorial distribution the Greater Accra region received a greater share of total registered project in terms of number of projects and the estimated value of projects whereas the service sector absorbed a lion share of the number projects whilst building and construction accumulated the highest estimated value of the total estimated cost of these registered projects. Table 1 and Table 2 show regional and sectorial distribution of registered projects in 2013 respectively.

Conversely, according to the Ghana Investment Promotion Centre, there were 183 registered projects representing a decline in the number of number projects registered reflecting a 227.17 percent decreased between 2013 and 2014. The breakdown of the total estimated cost indicated that, 44.57 percent in the manufacturing sector, 41.05 percent in service, 3.24 percent in general trading, 8.26\% in liaison sector, $0.46 \%$ in export trade, $0.70 \%$ in building and construction, $0.73 \%$ and $0.96 \%$ in the agriculture and tourism sectors respectively whereas Greater Accra region received the highest number of registered projects. Table 3 and Figure 4 show the sectorial and regional distribution of the registered projects. 
Table 1. Regional distribution of FDI registered projects in 2013.

\begin{tabular}{ccc}
\hline Region & Number of registered projects & Estimated value of Projects (US\$M) \\
\hline Ashanti & 27 & 294.93 \\
Brong-Ahafo & 4 & 10.14 \\
Central & 8 & 5.75 \\
Eastern & 4 & 3.91 \\
Greater Accra & 339 & 3560.04 \\
Northern & 2 & 1.08 \\
Upper East & 1 & 0.15 \\
Upper West & 1 & 0.01 \\
Volta & 10 & 27.67 \\
Western & 22 & 357.54 \\
Total & 418 & $\mathbf{4 2 6 1 . 2 2}$ \\
\hline
\end{tabular}

Source: Ghana Investment Promotion Centre.

Table 2. Sectorial distribution of FDI registered projects in 2013.

\begin{tabular}{ccc}
\hline Sectors & Number of Projects & Total estimated value (\$M) \\
\hline Agriculture & 14 & 154.44 \\
Building \&Construction & 61 & 1497.63 \\
Export Trade & 12 & 10.71 \\
General Trading & 90 & 307.89 \\
Liaison & 25 & 646.06 \\
Manufacturing & 63 & 520.93 \\
Service & 131 & 1058.87 \\
Tourism & 22 & 64.72 \\
Total & 418 & 4261.22 \\
\hline
\end{tabular}

Source: Ghana Investment Promotion Centre.

Table 3. Sectorial distribution of registered projects in 2014 .

\begin{tabular}{ccc}
\hline Sectors & Number of Projects & Total estimated value $(\mathbf{\$ M})$ \\
\hline Agriculture & 7 & 22.95 \\
Building \&Construction & 8 & 21.90 \\
Export Trade & 12 & 14.47 \\
General Trading & 29 & 101.35 \\
Liaison & 28 & 257.86 \\
Manufacturing & 57 & 1391.35 \\
Service & 38 & 1281.59 \\
Tourism & 4 & 29.98 \\
Total & 183 & 3121.45 \\
\hline
\end{tabular}

Source: Ghana Investment Promotion Centre. 
Table 3 clearly shows that, the manufacturing sector received the highest share in terms of number of projects and estimated value of projects.

Figure 4 shows that, the registered number of projects were distributed among six (6) regions out of the ten regions. Some regions were not captured in the regional distribution of FDI total estimated aggregate projects accumulated in 2014 fiscal year of investment. This is because there were no newly allocated foreign direct investment projects to these regions. However, Brong-Ahafo, Upper East, Upper West and Volta were the regions which did not appeared in Figure 4. Additionally, there was a continuous decrease in the number of registered projects and the total estimated cost of the registered projects between 2013 and 2015. There was a total of 170 registered projects through foreign direct investment by investors in 2015 of which the total estimated cost of the registered projects allocated to each sector were as follows 42.33 percent were in the service sector, 6.33 percent in the manufacturing sector, $0.34 \%$ in liaison, $4.90 \%$ in general trading, 21.99 percent in building and construction, $1.05 \%$ in export trade, 0.61 percent in agriculture and 22.42 percent in the tourism sector. Table 4

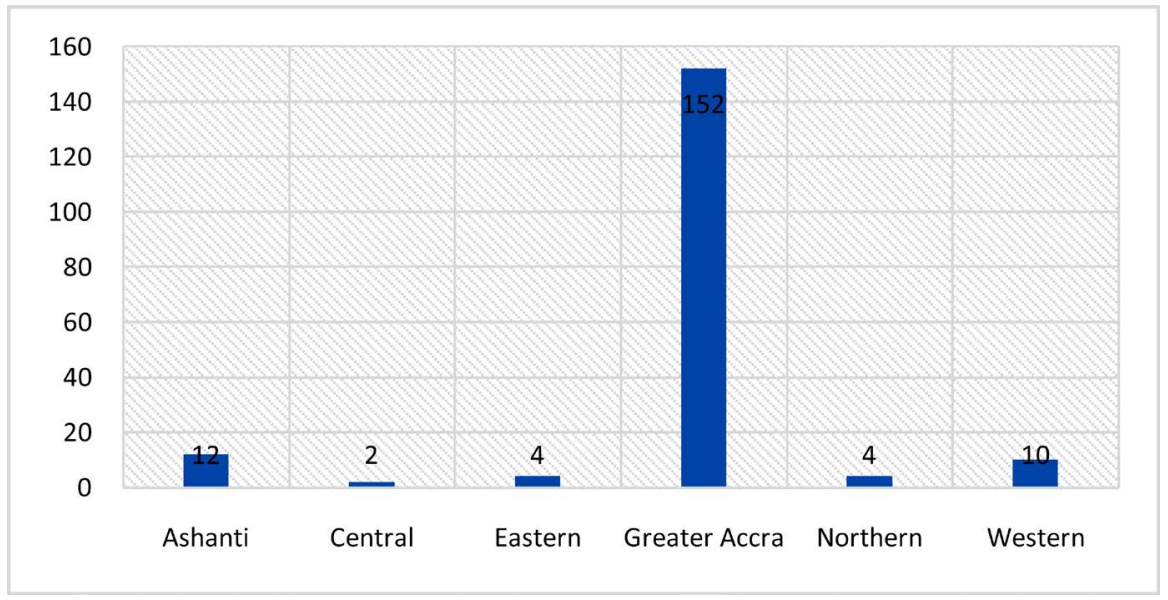

Source: Ghana Investment Promotion Centre.

Figure 4. Regional distributional of the total number of FDI registered projects in 2014.

Table 4. Sectorial distribution of registered projects in 2015.

\begin{tabular}{ccc}
\hline Sectors & Number of Projects & Total estimated value $\mathbf{( \$ \mathbf { M } )}$ \\
\hline Agriculture & 3 & 16.48 \\
Building \& Construction & 19 & 589.63 \\
Export Trade & 6 & 28.39 \\
General Trading & 21 & 131.50 \\
Liaison & 22 & 9.34 \\
Manufacturing & 41 & 169.62 \\
Service & 55 & 1134.55 \\
Tourism & 3 & 601.09 \\
Total & 170 & 2680.60
\end{tabular}

Source: Ghana Investment Promotion Centre. 
and Figure 5 shows the sectorial and regional distribution of the total number of registered projects recorded in 2015.

Figure 5 clearly indicates that, there was an increase in the number of regions which received the registered projects. Only two regions did not record any project in 2015. Considering the number of registered projects allocated to the Greater Accra region compared to 2014 indicates a decline, as a result of a reduction in the total number of registered projects recorded in 2015 and also an increase in the quantity of registered projects distributed to the other regions. Furthermore, there was an increase in the foreign direct investment inflow in terms of the number of projects and a reduction in the aggregate value in 2016 compared to 2015 as the Ghana Investment Promotion Centre recorded 180 registered projects. Table 5 and Figure 6 show sectorial and regional distribution of the total projects in 2016.

Moreover, during the 2017 investment fiscal year, eight out of the ten regions

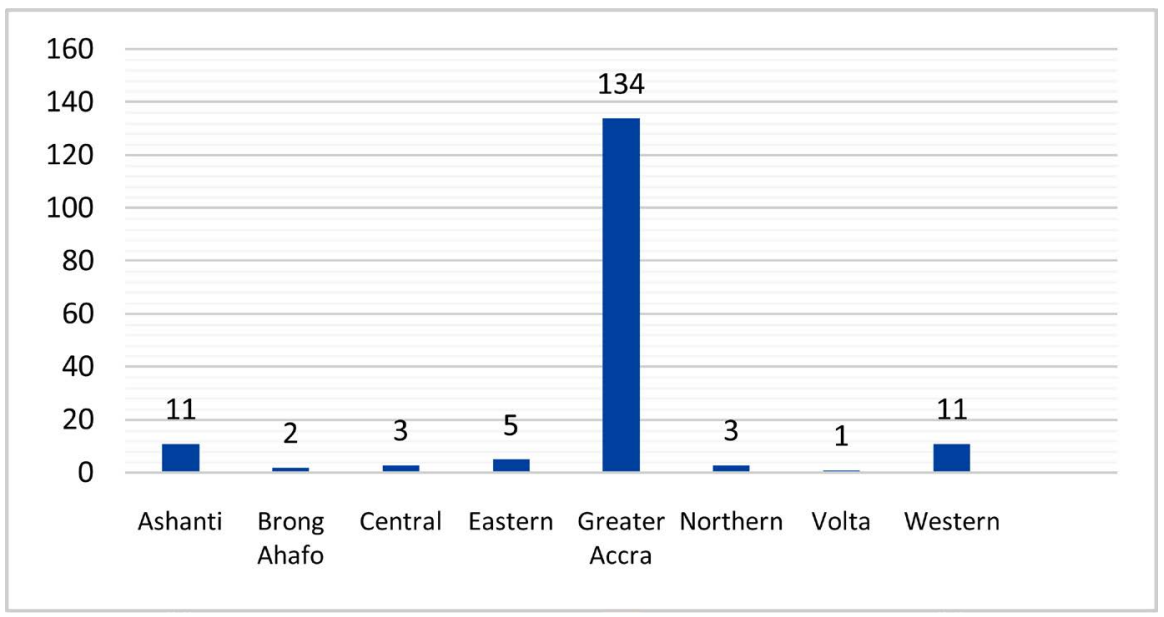

Source: Ghana Investment Promotion Centre.

Figure 5. Regional distributional of the total number of FDI registered projects in 2015.

Table 5. Sectorial distribution of registered projects in 2016.

\begin{tabular}{ccc}
\hline Sectors & Number of Projects & Total estimated value (\$M) \\
\hline Agriculture & 4 & 9.68 \\
Building \& Construction & 18 & 237.82 \\
Export Trade & 2 & 1.00 \\
General Trading & 22 & 52.63 \\
Liaison & 24 & 32.27 \\
Manufacturing & 39 & 351.54 \\
Service & 69 & 1747.64 \\
Tourism & 2 & 0.92 \\
Total & $\mathbf{1 8 0}$ & $\mathbf{2 4 3 3 . 5}$
\end{tabular}

Source: Ghana Investment Promotion Centre. 
directly gained from the 192 total registered projects. A greater percentage of all the registered projects were located in the Greater Accra region and on the other hand between the first and third quarters the manufacturing sector received the highest share in three quarters followed by the service sector. Table 6 and Figure 7 show the sectorial and regional distribution of the total registered projects in 2017.

\section{Discussion of the Investment Situation}

The political motive about regions perceive by people which influence politicians in economic and developmental decisions cannot be considered as a factor which influence the distribution of foreign direct investment registered projects in the Ghanaian economy. However, the ultimate motive of every investor is to make profit hence location is a key factor investors take into account when investing in a specific geographical area. In population wide, the Greater Accra

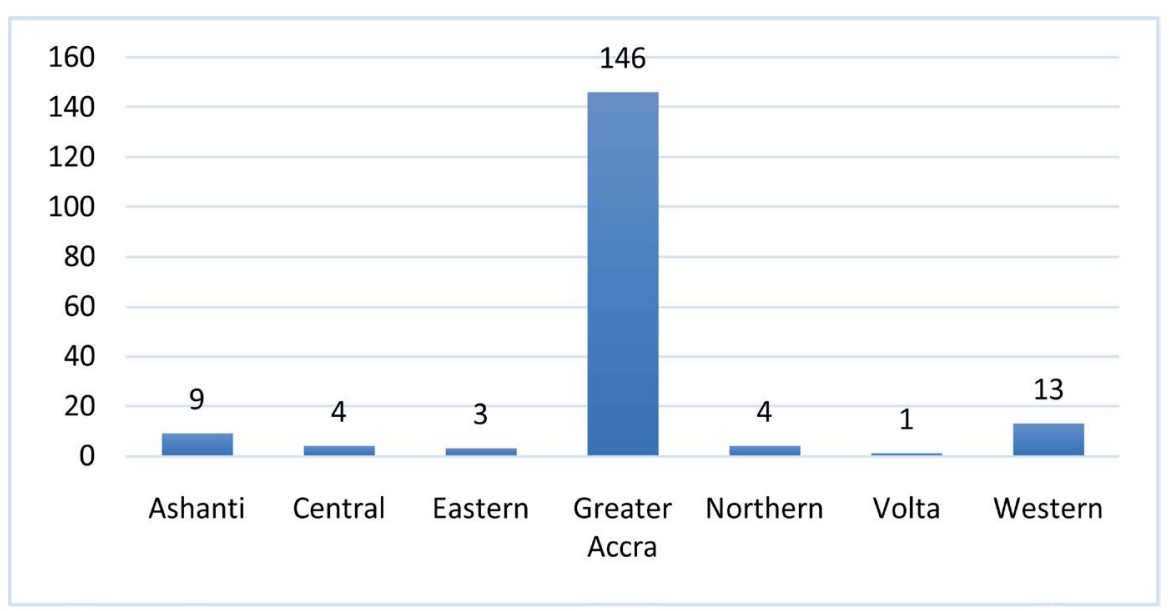

Source: Ghana Investment Promotion Centre.

Figure 6. Regional distributional of the total number of FDI registered projects in 2016.

Table 6. Sectorial Distribution of Registered Projects in 2017.

\begin{tabular}{cccc}
\hline $\begin{array}{c}\text { Sectorial Composition } \\
\text { of New Projects }\end{array}$ & $\begin{array}{c}\text { Newly Registered } \\
\text { Projects }\end{array}$ & $\begin{array}{c}\text { Estimated Value of } \\
\text { Projects (US } \$ \text { M) }\end{array}$ & \% of Estimated Value \\
\hline Agriculture & 1 & 6.91 & 0.3 \\
Building \& construction & 10 & 31.94 & 0.9 \\
Export Trade & 3 & 4.55 & 0.1 \\
General Trading & 26 & 44.67 & 1.3 \\
Liaison & 28 & 412.72 & 12.3 \\
Manufacturing & 37 & 2648.75 & 78.7 \\
Service & 34 & 217.13 & 6.4 \\
Tourism & 0 & 0 & 0 \\
Total & 139 & 3366.68 & 100 \\
\hline
\end{tabular}

Source: Ghana Investment Promotion Centre first-third quarter reports (2017). 


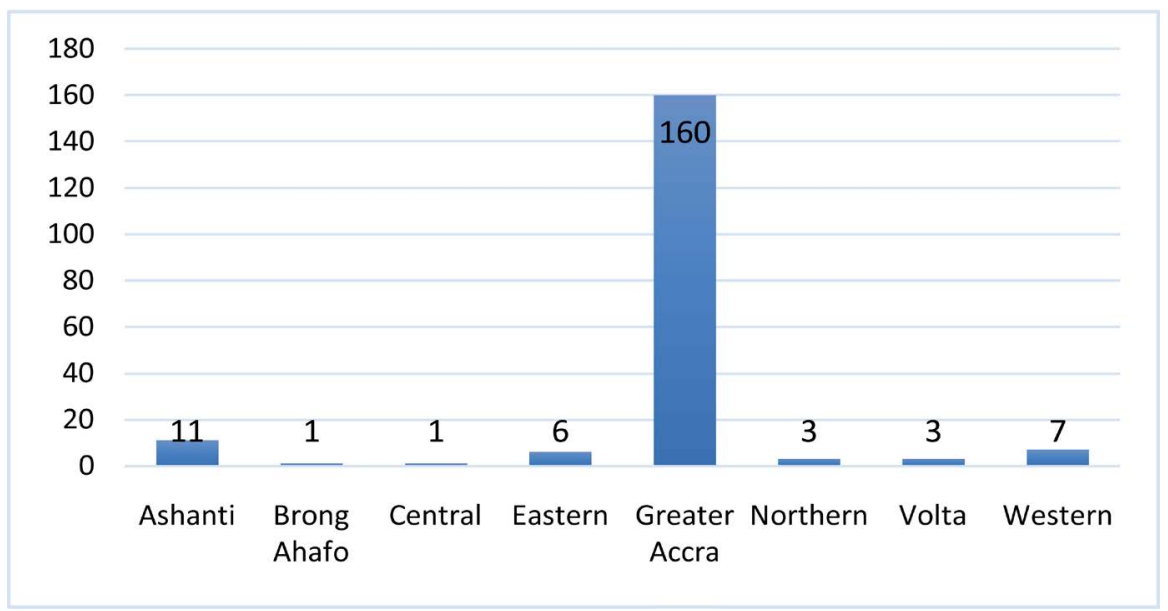

Source: Ghana Investment Promotion Centre.

Figure 7. Regional distributional of the total number of FDI registered projects in 2017.

region has the second largest inhabitants whiles the most populated region is the Ashanti. Conversely, availability of ready market for investors and profit margin affects the distributions of registered projects because the purchasing power of the people within which these registered projects are located also counts when taking an investing decision in an economic perspective. On the other hand, decisions toward the allocation and distribution among the various regions and sectors depend on each sector and region contribution to economic and the gross domestic growth. For instance, the service sector received majority of the total foreign direct investment registered projects between 1994 and 2013 due to its massive contribution to country's gross domestic product and economic growth compared to the other sectors over the years. Infrastructural development through foreign direct investment is centered in the Greater Accra region with the notion of having Accra as the capital of Ghana. Additionally, many industries are located in the Greater Accra region hence attracting more foreign direct investment projects every investment fiscal year. Moreover, with the government intention of making some areas special economic zones also affect the distribution and allocation of FDI registered projects.

\section{Conclusion}

In spite of the political and external pressure exerted by some financial instructions through foreign direct investment in Ghana and most African countries, foreign investment inflows continue to grow in terms of number of registered projects and percentage share of the world's total FDI inflow by investors into developing countries' economies. Investment restrictions directly and indirectly influence the distribution of foreign direct investment projects in certain vital regions and sectors in the Ghanaian economy leaving other sectors and regions not benefiting from these investment activities. Conversely, FDI projects and massive development are centered in the Greater Accra region with less attention focused on some regions like Upper East and Upper West. It is suggested 
that, foreign investment activities should not focus on some specific regions if the Ghana wants a universal development and an equal well-being of its citizens. This may not be sufficient to capture the benefits and the number of employments which can be created through the distribution and allocation of foreign direct investment projects for the people in the Upper East, Upper West and other regions which are considered among the poorest regions in Ghana. However, the long-standing Ghana's political environment serves as a motivation to most foreign investors to come and invest in its economy. Hence, this paper reveals some key regions and sectors which are profitable for investment activities in order to provide some important information to investors who would like to enquire much insight about the investment atmosphere and conditions before investing in Ghana.

\section{Acknowledgements}

Authors' profound gratitude goes to Professor Gang Tian of the School of Management, Jiangsu University, Yu Jing, associate professor of the school of Economics and Management, Nanjing University of Science and Technology and Evans Frimpong Boateng of Nanjing Agriculture University for every support rendered in making this work a reality. Thank you so much.

\section{Conflicts of Interest}

The authors declare no conflicts of interest regarding the publication of this paper.

\section{References}

[1] Abodakpi, J.Y. (2015) Chinese Investment in Ghana. Argumenta Oeconomica Cracoviensia, No. 13, 61-81. https://doi.org/10.15678/AOC.2015.1304

[2] UNCTAD. (1998) World Investment Report: Trends and Determinants. United Nations Conference on Trade and Development, New York and Geneva.

[3] Dunning, J. (1993) Multinational Enterprises and the Global Economy. Addisson-Wesley Publishing.

[4] Reuters. (2007) Ghana to Supply China Cocoa under Dam Funding Deal.

[5] Evans, Y. (2018) Foreign Direct Investment in Ghana: The Distribution among the Sectors and Regions. International Journal of Current Research, 6, 64292-64297.

[6] Apana, G.A. (2018) FDI Inflows and Outflows in Ghana and Its Exports and Import. Journal of Economics and Sustainable Development, 10, No. 9.

[7] GSS. (2017) Provisional 2016 Annual Gross Domestic Product. Ghana Statistical Service.

[8] Yu, J.Y. (2018) The Performance of the Tourism Sector towards FDI Attraction among Other Sectors of the Ghana Economy. European Scientific Journal, 14, No. 16.

[9] Abdul-Aziz, I.M. (2015) The Impact of Foreign Direct Investment (FDI) on the Performance of the Agricultural Sector in Ghana. International Journal of Academic Research in Business and Social Sciences, 5, No. 7.

[10] Kwasi, B.G.A. (2016) The Linkage between China's Foreign Direct Investment and 
Ghana's Building and Construction Sector Performance. Eurasian Journal of Business and Economics, 9, 81-97. https://doi.org/10.17015/ejbe.2016.018.05

[11] Dr. John, A.A. (2005) What Has Been the Impact of Foreign Direct Investment in Ghana? IEA Policy Analysis. The Institute of Economic Affairs, 1, No. 9.

[12] Decai, T.A. (2012) China-Africa Foreign Trade Policies: The Impact of China's Foreign Direct Investment (FDI) Flow on Employment of Ghana. Energy Procedia, 16, 553-557.

[13] Kwaku, T.Y. (2000) Determinants of Foreign Direct Investment in Ghana. Overseas Development Institute.

[14] Service, G.S. (2018) Provisional 2017 Annual Gross Domestic Product. Ghana Statistical Service. 